\title{
Kontaminasi Pestisida Organoklorin pada Sedimen dan Air Laut dan Pengaruhnya Terhadap Kelimpahan Makrozoobenthos di Pesisir Jepara
}

\author{
Chrisna Adhi Suryono*, Ken Suwartimah, Baskoro Rochaddi dan Sarjito \\ Jurusan IImu Kelautan, Fakultas Perikanan dan IImu Kelautan, Universitas Diponegoro. \\ JI. Prof. Soedarto, SH. Kampus UNDIP Tembalang, Semarang 50275 \\ Email : chrisna_as@yahoo.com
}

\begin{abstract}
Abstrak
Senyawa pestisida merupaka senyawa persisten yang sangat sulit diuraikan dan akan terakumulasi dalam lemak suatu organisme. Tujuan dari penelitian ini adalah untuk mengetahui keberadaan senyawa pestisida dan keterkainya dengan keanekaragaman makrozoobenthos di perairan Mlonggo Jepara. Metode survey digunakan dalam penelitian ini dengan mengambil 3 lokasi titik sampling dan ulangan sebanyak 4 kali. Hasil penelitian menunjukan daerah muara sungai (stasiun II) menunjukan kandungan pestisida yang lebih tinggi dan keanekaragaman hewan makrozoobenthos yang rendah bila dibandingkan dengan stasiun I (perairan sungai) dan stasiun III (perairan laut).
\end{abstract}

Kata kunci: Pestisida, akumulasi dan makrozoobenthos

\begin{abstract}
The pesticide compound has characteristic difficult to degrade in the nature and accumulate in fat tissue of organism. The purpose o the research was conducting the existing of pesticide compound on Mlonggo waters and their correlation to macrozoobenthic diversity. Sampling survey method was applied on this research which take place on 3 station and 4 replicate. The present research show, that the location on the mouth of river (station II) has the highest concentration of pesticide compound and lowest of macrozoobenthic diversity compared with stations I and III which located on the river and sea.
\end{abstract}

Keywords: Pesticide, accumulation and macrozoobenthic

\section{PENDAHULUAN}

Daerah pesisir pantai Mlonggo Jepara yang sebagian besar daratan pesisirnya dipergunakan untuk intensifikasi budidaya pertanian memungkinan pencemaran garam-garam dari berbagai senyawa halogen yang disebabkan oleh meningkatnya penggunaan bahan pestisida, herbisida, dan insektisida di dalam bidang pertanian. Polutan-polutan tersebut dapat menyebabkan tidak berfungsinya dan menurunnya kualitas lingkungan yang sangat merugikan bagi keseimbangan ekosistem organisme laut di perairan pantai. Senyawa pestisida organoklorin merupakan senyawa persisten yang sangat sulit diuraikan di alam dan akan terakumulasi dalam lemak suatu organisme. Senyawa tersebut bersifat karsinogen dan mutagen terhadap hewan (Sutamihardja, 1991).

Djajanto (1985) mengatakan bahwa 12 jenis pestisida yang dikategorikan 'extremely' atau 'highly' toksik bagi manusia maupun lingkungan oleh WHO terdapat 8 jenis di antaranya dipasarkan di Indonesia, yaitu, $\mathrm{HCH}$ atau Lindane, Chlordane atau Heptachlor, DDT, Aldrin (Dieldrin dan Endrin), Paraquat, Parathion, EDB dan 2,4,5 T. Meningkatnya jenis dan 
volume penggunaan senyawa-senyawa kimia tersebut di Indonesia tidak lepas dari pencanangan program rehabilitasi perkebunan pada tahun 1960 (Djamin, 1983) dan program revolusi hijau ('green revolution') melalui Panca Usaha Pertanian pada tahun 1970 oleh pemerintah (Anonim, 1987). Sehingga perlu dievaluasi kembali data tentang toksisitas pestisida dan dampaknya terhadap lingkungan.

Adanya residu pestisida organoklorin pada sedimen dan air laut diduga akan mempengaruhi kehidupan dan keanekaragaman makrozoobenthos yang berada di dalamnya. Tujuan dari penelitian ini adalah untuk mengetahui kondisi kualitas perairan pantai Mlonggo dengan mendeteksi keberadaan senyawa pestisida organoklorin pada sedimen dan air laut, keanekaragaman makrozoobenthos.

\section{MATERI DAN METODE}

Materi yang digunakan dalam penelitian ini adalah sampel sedimen yang diambil dari perairan Mlonggo kemudian dianalisa kandungan pestisida, hewan makrobenhos, dan kandungan bahan organik.

\section{Sampling}

Sampling sedimen dan air laut dilakukan secara 'stratified random' pada 3 stasiun yang ditentukan dengan jarak masing-masing 0, 500 dan 1000 meter dari tengah estuaria kearah laut dengan bottom sampler grab dan botol nansen.

\section{Analisis Makrozoobenthos}

Sampel sedimen yang diperoleh diayak dengan saringan $0.5 \mathrm{~mm}$ guna memisahkan substrat dan kotoran. Sampel benthos yang diperoleh kemudian diawetkan dengan formali $4 \%$ dan beberapa tetes rose bengale. Identifikasi dilakukan di laboratorium dengan menggunakan buku kunci identifikasi Robert et al. (1982).

\section{Analisis Residu Pestisida Organoklorin}

Analisis residu organoklorin akan dilakukan menurut prosedur yang dilakukan oleh Hamidah (1994).

a. Sampel air

Sampel air laut sebanyak 50 liter disaring dengan menggunakan filter 'glass fiber' dengan diameter $293 \mathrm{~mm}$. Hasil saringan diekstrak dengan $\mathrm{n}$ hexana selama 4 jam dengan menggunakan alat 'liquid-liquid extractor, kemudian destilatnya diuapkan dengan Kuderna Danish sampai volume mencapai $1 \mathrm{ml}$.

Tahap berikutnya dilakukan 'clean
up' yang berguna untuk
menghilangkan senyawa-senyawa
lainnya yang mengganggu, dengan
cara memberikan $\mathrm{Al}_{2} \mathrm{O}_{3}$ yang
dilewatkan dalam n-hexana. Setelah itu
dilakukan dengan proses pemisahan
fraksi yang kurang polar (P1) dan lebih
polar (P2) dengan cara melewatkan $\mathrm{n}$ -
hexana kedalam botol yang berisi dilika
untuk $\mathrm{P} 1$, dan penambahan $10 \%$ etil
dalam n-hexana untuk mendapatkan
P2. Selanjutnya kadar pestisida
organoklorin diukur dengan alat Gas
Chromatography.

b. Sampel sedimen

Sampel sedimen diambil dengan menggunakan grab dan disimpan dalam botol kaca yang tutupnya dilapisi alumunium foil. Kemudian dari sampel, diambil sebanyak 40-50 gram dan dipanaskan dalam oven dengan suhu $50^{\circ} \mathrm{C}$ selama 24 jam. Selanjutnya dilakukan penambahan $\mathrm{Na} 2 \mathrm{SO} 4$ sampai homogen untuk menarik air yang masih terdapat dalam sedimen. Setelah itu sampel diekstrak ke dalam dimetilen chlorida dengan menggunakan soxlet selama 8 jam. Proses selanjutnya sama seperti prosedur dengan menggunakan sampel air.

Perhitungan :

Kadar contoh $=\mathrm{Tpc} / \mathrm{Tps} \times \mathrm{kc} \times 1000 \times 1 / \mathrm{bc}$ 
Keterangan:

Tpc = tinggi peak contoh

Tps = tinggi peak standard

$\mathrm{Kc}=$ konsentrasi contoh

$\mathrm{BC}=$ berat contoh

\section{Analisis Data}

Indeks keanekaragaman dan keserahgaman dihitung dengan menggunakan rumus:

a. Nilai Indeks Keanekaragaman (Shanon dan Weaver, 1949 dalam Krebs, 1985) :

$$
\begin{aligned}
H= & -\sum_{i=1}^{s}(p i)(\log 2 p i) \\
H= & \text { Indek diversity } \\
\mathrm{S}= & \text { jumlah spesies } \\
\mathrm{pi}= & \text { perbandingan jumlah spesies } . \mathrm{i} \text { (ni) } \\
& \text { terhadap jumlah semua spesies (N) } \\
& =(\mathrm{ni} / \mathrm{N})
\end{aligned}
$$

b. Nilai indeks keseragaman (Krebs, 1985) :

$$
\boldsymbol{E}=\frac{\boldsymbol{H}}{\boldsymbol{H} \max }
$$

$\mathrm{E}=$ Indek kesamaan = Equitability

$\mathrm{H} \quad=$ Indek diversity yang diamaty

$\mathrm{H}$ max $=$ Maksimum spesies diversity $\left(\log _{2} \mathrm{~S}\right)$

Untuk mengetahui korelasi antara residu organoklorin dan indeks keanekaragaman digunakan analisa regresi sederhana dengan program Minitab 10. Persamaan matematis:

$$
Y=a+b \cdot X
$$

Keterangan :

$Y=$ variabel dependent

$X=$ variabel independent (residu organoklorin)

$a=$ intersep

$\mathrm{b}=$ koefisien regresi

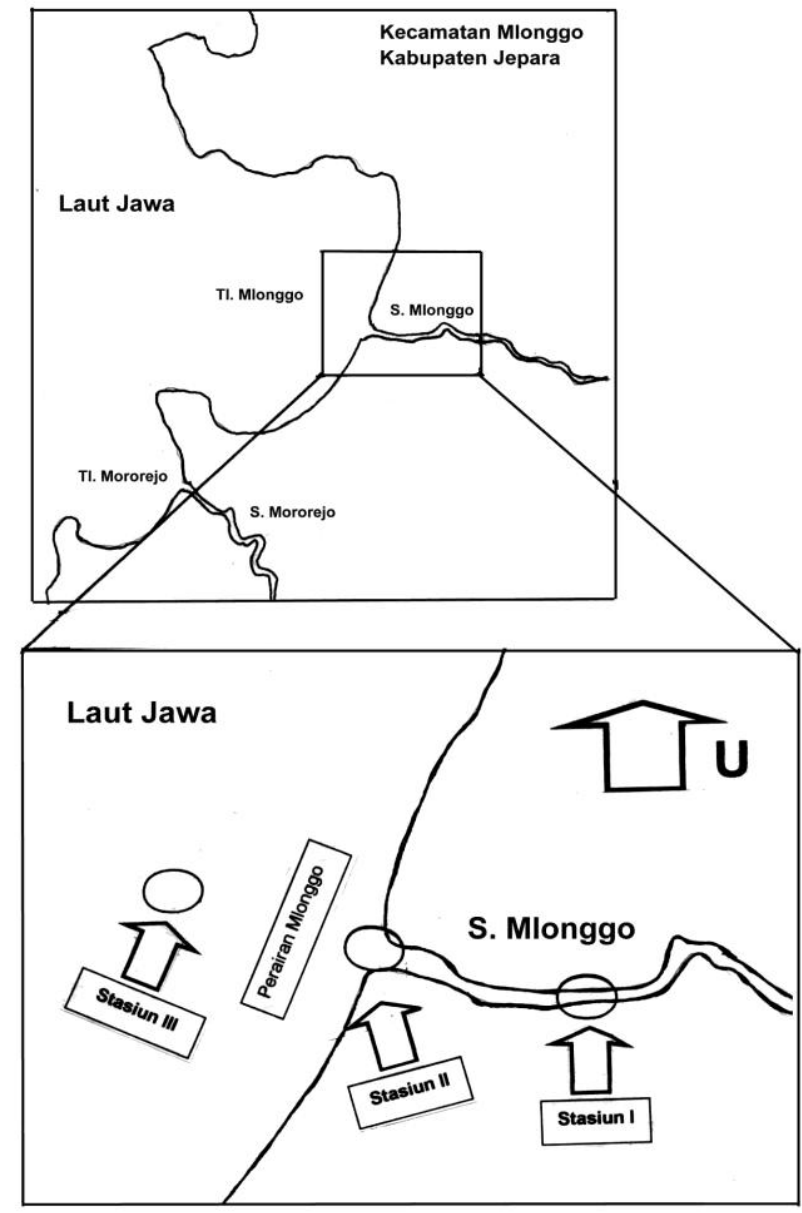

Gambar 1. Lokasi penelitian dan 3 lokasi stasiun sampling 


\section{HASIL DAN PEMBAHASAN}

$\begin{array}{ccc}\text { Hasil penelitian memperlihatkan } & \begin{array}{c}\text { memakrobenthos, } \\ \text { bahwa }\end{array}\end{array}$ keanekaraman dan kesamaan jenis dapat dilihat dalam Tabel 1. Dalam tabel tersebut terlihat bahwa jumlah hewan makro benthos terbanyak terdapat pada stasiun II sebesar 364 ind/ $\mathrm{m}^{2}$, kemudian stasiun I sebesar $184 \mathrm{ind} / \mathrm{m}^{2}$ dan stasiun III sebesar 152 ind/ $\mathrm{m}^{2}$. Sedangkan kalu dilihat dari indek keanekaragam terbesar terdapat pada stasiun III sebesar 2,806 kemudian diikuti oleh stasiun I sebesar 2,698 dan terkecil pada stasiun I sebesar 1,831. Kandungan pestisida dalam perairan Mlonggo dapat dilihat dalam Tabel 2. Dalam tabel tersebut terlihat kandungan terkecil masing masing jenis pestisida terdapat pada stasiun III baik dalam air maupun sedimen sedangkan yang paling besar terdapat dalam stasiun II.

Bila dlihat dari kondisi perairan pantai Mlonggo yag terdapat pada dasar perairan terlihat bahwa salinitas terendah rata rata terdapat pada stasiun I $(27,1 \%$ o) dan tertinggi pada stasiun III $(32,7 \% \circ)$ dan kandungan bahan organic tertinggi terdapat pada stasiun I $(12,66 \%)$ dan terendah terdapat pada stasiun $\|(9,68 \%)$. Hasil uju regresi terhadap pp-DDT dalam sedimen terhadap keanekaragaman hewan makrobenthos pada masing masing stasiun menunjukan bahwa pada stasiun I $r^{2}=0,88$ dan untuk stasiun $\|$ nilai $r^{2}=0,67$ sedang untuk stasiun III nilai $r^{2}=0,94$.

Hasil penelitian keanekaragaman hewan makro benthos di perairan Mlonggo menunjukan bahwa keanekaragaman tertinggi terdapat pada stasiun III $(2,806)$ kemudian diikuti pada stasiun I $(2,698)$ dan terendah pada stasiun II $(1,831)$. Kondis tersebut sebenearnya dapat dipahami karena pada stasium III kondisi dasar perairannya lebih baik bila dibandingkan dengan stasiun II dimana pada stasiun III kandungan pestisidanya paling rendah bila dibandingkan dengan stasiun II maupun stasiun I.

Seperti kita ketahui pestisida merupakan unsur hidrokarbon yang toksik yang dapat terakumulasi dalam jaringan organisme. Keberadaan pestisida dalam perairan laut umumnya terbawa oleh aliran sungai dan dari atmosfir yang jatuh bersamaan denga hujan dan sebagian besar disumbangkan dari aktifitas pertanian (Clark, 1989). Daerah sekitar perairan Mlonggo merupakan daerah persawahan diduga masuknya pestisida dapat langsung melalui aliran sungai dan terakumulasikan dalam sedimen perairan tersebut hal tersebut bisa dilihat dengan tingginya untuk semua jenis pestisida pada stasiun II bila dibandingkan dengan yang terdapat pada stasiun I dan III.

Tingginya kandungan pestisida dalam sedimen tentunya akan berdampak pada organisme yang ada didalamnya sperti hewan makrobenthos, hal ini tercermin dengan rendahnya nilai indek keanekaragaman yang ada pada stasiun II bila dibandungkan dengan syasiun I dan III. Beberapa penelitaian pengaruh bahan pestisida terhadap organisme laut telah diiformasikan seperti yang dikakukan oleh Brown (1978) yang menginformasikan bahwa pestisida organoklorin dalam konsentrasi yang sangat rendah dapat menekan pertumbuhan makrozoobenthos. Lebih lanjut Brown (1978) melaporkan bahwa dalam suatu perairan yang tercemar DDT 1 ppm, pertumbuhan Crassostrea virginica tereduksi sebesar $95 \%$ hanya dalam waktu satu minggu. Demikian pula pada oyster, meskipun dapat tumbuh normal pada konsentrasi 10 $\mathrm{ppb}$, namun pembentukan cangkang dapat terhambat. Pada konsentrasi 0,1 ppb DDT dapat mereduksi pembentukan cangkang sekitar $80 \%$. Eisler (1969), dalam Glynn et al.(1985) mengatakan bahwa pestisida organoklorin dapat menghambat produktivitas fitoplankton, membunuh crustacea, ikan dan moluska.

Dari informasi tersebut terlihat dengan jelas bahwa pestisida sangat memberi dampak yang sangat buruk bagi organisme perairan terlebih lebih ditambah dengan rendahnya kandungan bahan organik sebagai bahan makanan untuk hewan makro benthos pada stasiun II bila dibandingkan dengan stasiun I dan III. Sebenarnya diversitas hewan makro benthos di suatu perairain tidak hanya 
Tabel 1. Jenis, jumlah,keanekaragam dan kesamaan jenis pada stasiun penelitian.

\begin{tabular}{|c|c|c|c|c|c|}
\hline \multicolumn{6}{|c|}{ Stasiun I } \\
\hline No & Benthos & Jumlah & $\mathrm{ni} / \mathrm{N}$ & $\mathrm{H}^{\prime}$ & $E$ \\
\hline 1 & Sergestidae & 4 & 0.022 & 0.120 & 0.038 \\
\hline 2 & Penaeus & 4 & 0.022 & 0.120 & 0.038 \\
\hline 3 & Exallopus & 20 & 0.109 & 0.348 & 0.110 \\
\hline 4 & Nephtyidae & 40 & 0.217 & 0.479 & 0.151 \\
\hline 5 & Leptonereis & 48 & 0.261 & 0.506 & 0.160 \\
\hline 6 & Atactodea & 4 & 0.022 & 0.120 & 0.038 \\
\hline 7 & Saccostrea & 36 & 0.196 & 0.460 & 0.145 \\
\hline 8 & Rhinoclavis & 20 & 0.109 & 0.348 & 0.110 \\
\hline 9 & Nassarius & 8 & 0.043 & 0.197 & 0.062 \\
\hline & Jumlah & 184 & 1 & 2.698 & 0.851 \\
\hline \multicolumn{6}{|c|}{ Stasiun II } \\
\hline No & Benthos & Jumlah & $\mathrm{ni} / \mathrm{N}$ & $\mathrm{H}^{\prime}$ & $E$ \\
\hline 1 & Caridea & 4 & 0.0110 & 0.072 & 0.023 \\
\hline 2 & Mysta & 4 & 0.0110 & 0.072 & 0.023 \\
\hline 3 & Ophelia & 4 & 0.0110 & 0.072 & 0.023 \\
\hline 4 & Pisionidens & 8 & 0.0220 & 0.121 & 0.038 \\
\hline 5 & Rhinoclavis & 216 & 0.5934 & 0.447 & 0.141 \\
\hline 6 & Turritella & 88 & 0.2418 & 0.495 & 0.156 \\
\hline 7 & Pseudovertagus & 12 & 0.0330 & 0.162 & 0.051 \\
\hline 8 & Strombus & 16 & 0.0440 & 0.198 & 0.063 \\
\hline 9 & Cirsotrema & 8 & 0.0220 & 0.121 & 0.038 \\
\hline 10 & Subcancilla & 4 & 0.0110 & 0.072 & 0.023 \\
\hline & Jumlah & 364 & 1 & 1.831 & 0.577 \\
\hline \multicolumn{6}{|c|}{ Stasiun III } \\
\hline No & Benthos & Jumlah & $\mathrm{ni} / \mathrm{N}$ & $\mathrm{H}^{\prime}$ & $\mathrm{E}$ \\
\hline 1 & Tanaidacea & 4 & 0.026 & 0.138 & 0.044 \\
\hline 2 & Gammaridae & 44 & 0.289 & 0.518 & 0.163 \\
\hline 3 & Capitella & 4 & 0.026 & 0.138 & 0.044 \\
\hline 4 & Leptonereis & 8 & 0.053 & 0.224 & 0.071 \\
\hline 5 & Aparonis & 12 & 0.079 & 0.289 & 0.091 \\
\hline 6 & Gafrarium & 4 & 0.026 & 0.138 & 0.044 \\
\hline 7 & Rhinoclavis & 32 & 0.211 & 0.473 & 0.149 \\
\hline 8 & Turritella & 32 & 0.211 & 0.473 & 0.149 \\
\hline 9 & Atya & 4 & 0.026 & 0.138 & 0.044 \\
\hline 10 & Natica & 4 & 0.026 & 0.138 & 0.044 \\
\hline 11 & Latirus & 4 & 0.026 & 0.138 & 0.044 \\
\hline & Jumlah & 152 & 1 & 2.806 & 0.885 \\
\hline
\end{tabular}

tergantung oleh satu faktor seperti pestisida naman banyak faktor yang mempengaruhinya baik faktor internal seperti sifat reproduksi, adaptasi dan dispersi juga karena faktor eksternal seperti pollutan, migrasi, pemangsaan dan kompetisi (Krebs, 1985). Jadi memang sangat tidak mungkin menyatakan eksitensi suatu popolasi dalam suatu habitat hanya disebabkan oleh satu faktor eksternal, masih sangat diperlukan beberapa penelitian yang mendalam secara laboratoris untuk mengetahui efeks pestisida terhadap hewan makrobenthos. 

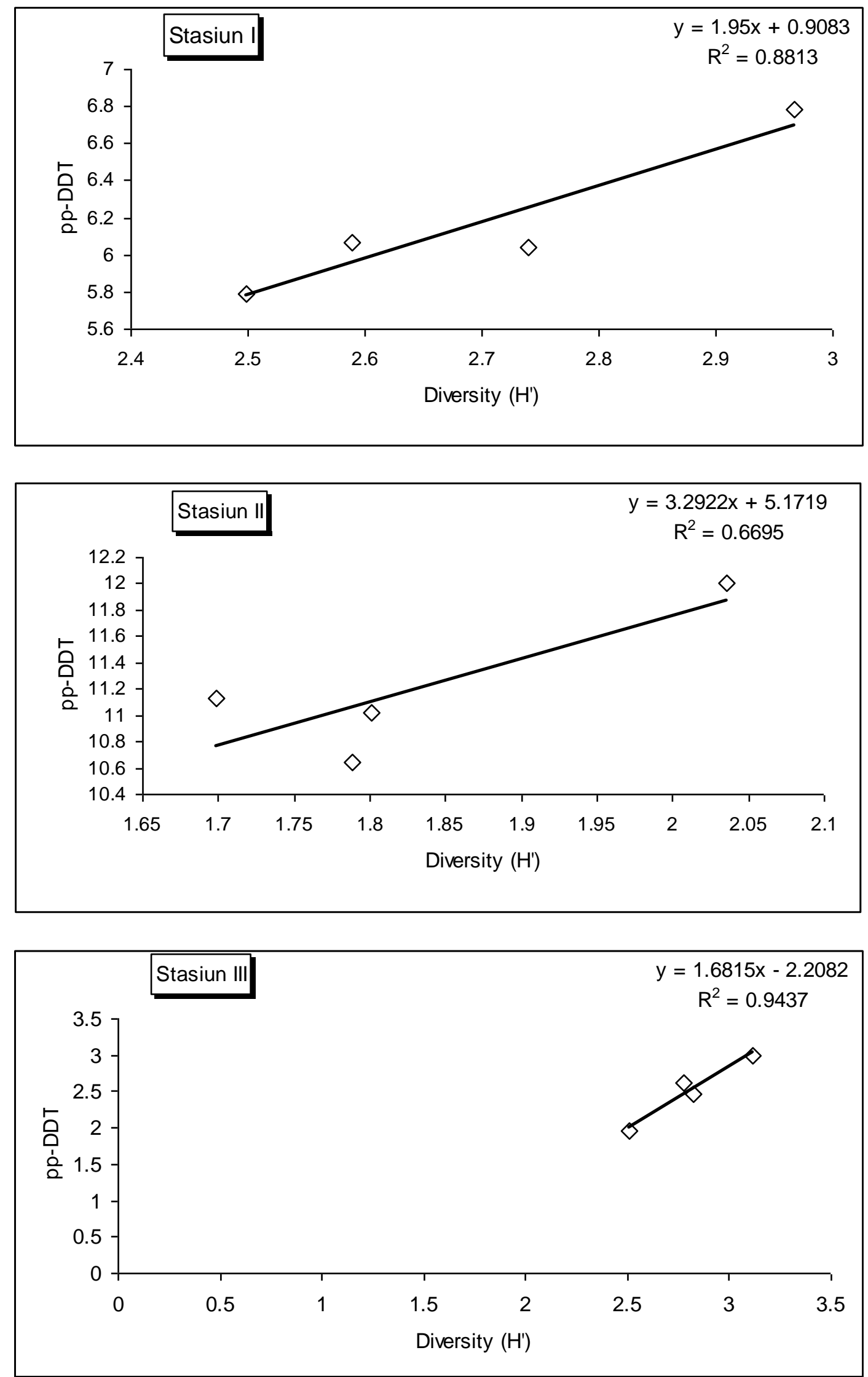

Gambar 2. Gambar grafik regresi dan korelasi antara diversity makrobenthos dan konsentrasi pp-DDT (ppb)dalam sedimen pada satisin I, II dan III. 
Tabel 2. Kandungan pestisida dalam sedimen dan air perairan Mlonggo

\begin{tabular}{ccccccc}
\hline \multirow{2}{*}{ Stasiun } & \multicolumn{7}{c}{ Konsentrasi Pestisida (ppb) } \\
\cline { 2 - 7 } & $\alpha$-BHC & $\beta$-BHC & pp-DDT & $\alpha$-BHC & $\beta$-BHC & pp-DDT \\
\cline { 2 - 7 } I & 0.31 & 1.42 & 1.02 & 4.02 & 6.12 & 6.17 \\
II & 0.87 & 1.94 & 2.38 & 12.11 & 16.41 & 11.21 \\
III & 0.36 & 1.47 & 0.74 & 3.17 & 6.02 & 2.51 \\
\hline
\end{tabular}

Tabel 3. Kondisi lingkunagn dasar perairan pantai Mlonggo

\begin{tabular}{cccccccc}
\hline \multirow{2}{*}{ Stasiun } & \multicolumn{7}{c}{ Kondisi Perairan } \\
\cline { 2 - 9 } & $\mathrm{n}$ & Salinitas & $\mathrm{DO}$ & Suhu & Kecerahan & $\mathrm{pH}$ & B.Organik \\
\hline \multirow{4}{*}{ I } & 1 & 26 & 7.22 & 28,4 & 1 & 7 & 10.8 \\
& 2 & 27.3 & 7.72 & 29,4 & 0.7 & 7 & 7.34 \\
& 3 & 27.6 & 7.02 & 29 & 0.8 & 7 & 15.38 \\
& 4 & 27.4 & 7.31 & 29,2 & 0.7 & 7 & 17.14 \\
& Rerata & 27.1 & 7.3175 & 7.25 & 0.8 & 7 & 12.665 \\
\hline \multirow{4}{*}{ II } & 1 & 31 & 7.26 & 28,8 & 0.5 & 7 & 14.6 \\
& 2 & 32 & 7.41 & 28,8 & 0.8 & 7 & 6.56 \\
& 3 & 32.5 & 7.38 & 29,6 & 0.4 & 7 & 9.68 \\
& 4 & 30 & 6.87 & 28,2 & 0.3 & 7 & 7.89 \\
& Rerata & 31.4 & 7.23 & 0 & 0.5 & 7 & 9.6825 \\
\hline \multirow{4}{*}{ III } & 1 & 32.1 & 7.52 & 28,8 & 1.8 & 7 & 4.4 \\
& 2 & 32.7 & 7.47 & 28,5 & 2 & 7 & 11.68 \\
& 3 & 32.8 & 7.55 & 29 & 2 & 7 & 10.13 \\
& 4 & 33 & 6.71 & 28 & 1.6 & 7 & 13.6 \\
& Rerata & 32.7 & 7.3125 & 14.25 & 1.85 & 7 & 9.9525 \\
\hline
\end{tabular}

\section{KESIMPULAN}

Dari hasil penelitian dapat disimpulkan bahwa hewan makro benthos yang terdapat di perairan Mlonggo sementara dapat dikatakan dipengaruhi oleh pestisida yang terdapat dalam perairan baik sedimen maupun air

\section{DAFTAR PUSTAKA}

Brown, A.W.A. 1978. Ecological pesticides. John Willey and Sons. New York. $127 \mathrm{p}$

Clark, R.B. 1989. Marine pllution. Oxford Science Publications. Oxford. $220 \mathrm{p}$.

Djamin, A. 1983. Pesticide Management in plantation in North Sumatra. A peper presented in regional symposium on plantation environments, Indonesia.

Djayanto, W. 1985. Chemical are 'no problem' in Indonesia. Jakarta Post, Nov 7.

Eltringham, S.K. 1971. Life in mud and sand. Crane, New York, 39 - 55 pp.

Glynn, P.W., Howard, L.S., Corcoran, E and Freay, A. D. $1985 . \quad$ Preliminary investigations into the occurrence and toxicity of commercial herbicide formulations in reef building corals. Proc. Int. Coral Reef, 1985.

Hamidah, R. 1991. Khromatografi gas untuk penentuan organoklorin dari poliklorobifenil. LON _ LIPI. Jakarta. 41 -45 hal.

Krebs, C.J. 1985. Ecology: The experimental analysis of distribution and 
abundance. Harper \& Row Publishers, New York. 800 p.

Noegrohati, 1993. Petunjuk laboratorium analisis petisida organoklorin. Gajah Mada Press. 285 hal.

Odum, E.P. 1971. Fundamental of ecology. W.B Sounders Company. Toronto. 547 p.
Robert, D., Kastoro, W.W and Somodihardjo, S. 1982. Shallow water marine mollusks of North West Java. Lon-LIPI. Jakarta. 140 pp. 